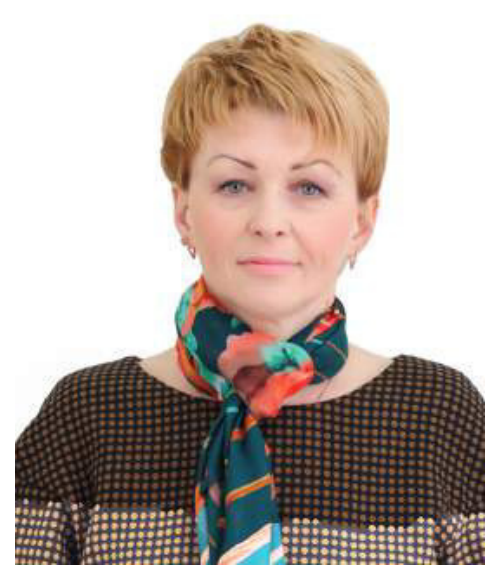

\title{
ДИНАМІКА РОЗВИТКУ СІЛЬСЬКИХ МАЛОЧИСЕЛЬНИХ ШКІЛ ГІРСЬКОГО РЕГІОНУ ІВАНО-ФРАНКІВЩИНИ (2000-2016 РР.)
}

\section{DYNAMICS OF DEVELOPMENT OF VILLAGE SMALL SCHOOLS IN IVANO-FRANKIVSK MOUNTAIN REGIONS (2000-2016)}

у статті досліджені питання динаміки розвитку малочисельної школи гірського регіону. Проаналізовано взаємозалежність спаду населення України і існування малочисельної школи. Розглянуто можливості існування малої школи в Українських Карпатах. Автор пояснює особливості розвитку малочисельної школи в сучасних умовах, етапи та концепції навчання в таких школах, пропонує основні шляхи вирішення вище згаданої проблеми.

У статті представлено статистичні дані щодо чисельності населення гірських регіонів, а також показано динаміку існування малочисельних шккіл гірських регіонів Івано-Франківщини.

Ключові слова: малочисельна школа, гірські райони, Івано-Франківщина, статистичні дані, динаміка розвитку.

This article is about the dynamics of the development a small school of the mountain region. The author analyzes the dependence of the decline of the population of Ukraine and the existence of a small school. The article considers the possibility of the existence of a small school in the Ukrainian Carpathians. The author explains the peculiarities of the development of a small school in modern conditions, stages and concepts of teaching in such schools, proposes the main ways of solving the above-mentioned problem.

The article shows the dynamics of the existence of small schools of mountain regions of Ivano-Frankivsk region.

Key words: small school, mountainous regions, Ivano-Frankivsk region, statistical data, development dynamics.

В статье исследованы вопросы динамики развития малочисленной школы горных регионов. Проанализированы взаимозависимость убыли населения Украины и существования малочисленной школы. Рассмотрены возможности существования малой школы в Украинских Карпатах. Автор объясняет особенности развития малочисленной школы в современных условиях, этапы и концепции обучения в таких школах, предлагает основные пути решения вышеупомянутой проблемы.

Ключевые слова: малочисленная школа, горные районы, Ивано-Франковская, статистические данные, динамика развития.

Постановка проблеми в загальному вигляді та її зв'язок з важливими науковими та практичними завданнями. Нові феномени українських повсякденних реалій поступово стають предметом важливих теоретичних та методологічних дискусій. У контексті нових підходів до української шкільної системи навчання, Концепції нової української школи змін потребує не лише навчальний процес у школах, реорганізовуватись та видозмінюватись мають і типи шкіл, підходи до їх існування загалом. Яке майбутнє чекає на малочисельні школи гірського регіону? Чи має право на існування така школа. Цій проблемі присвячено чимало дискусій та обговорень [4 ].

Висловлюємо думку про те, що сільська малочисельна школа , є особливою структурною ланкою збереження і розвитку не лише села, сільського господарства загалом, але і гарантом розвитку держави.

Аналіз останніх досліджень і публікацій, у яких започатковано розв'язання проблеми. На сьогодні чимало науковців досліджують питання життєдіяльності сучасної школи. Аналіз наукової літератури засвідчує, що значний внесок у питання роботи малокомплектних шкіл зроблено Н.Касярум, В.Лизогубом, Т.Павловою, Н.Присяжнюк, О.Савченко, Л. Стасюк та ін.

Зокрема, особливості теоретичного підходу до поняття малочисельних шкіл вивчають В. Мелешко, Н. Побірченко та ін. Становлення і розвиток екологічного виховання школярів у сільських малокомплектних школах Західної України (середина XX - початок XXI ст) вивчає Л. Стасюк. 
Специфіку навчально-виховного процесу малокомплектних шкіл проаналізовано Л. Присяжнюк.

В історичному аспекті самостійну роботу учнів у процесі вивчення дисциплін природничого циклу в малокомплектних школах Слобожанщини (60-90рр. XXст.) вивчив О. Пінський та ін.

Виділення невирішених раніше частин загальної проблеми, яким присвячується стаття. У даних наукових доробках все ж немає комплексного аналізу динаміки розвитку малочисельної школи другої половини XX ст. Актуальність проблеми, зацікавлення підходами до виховання учнів у сільських малокомплектних школах України зумовили вибір теми публікації. Зауважимо, що приведена нижче розвідка є продовженням циклу статей автора з окресленої проблематики [5].

Формування мети статті. Метою статті $є$ розкриття динаміки розвитку малочисельної школи гірських регіонів Івано-Франківщини.

Виклад основного матеріалу дослідження з повним обгрунтуванням отриманих наукових результатів. У ст. 14 Закону України «Про загальну середню освіту» зазначається, що в загальноосвітніх закладах, розташованих у селах, селищах, кількість учнів у класах визначається демографічною ситуацією, але повинна становити не менше п'яти осіб [3]. У подальших документах, спрямованих на роз'яснення Закону, поняття «малокомплектна школа» не фігурує, а такого типу заклади йменуються «малочисельні школи» або «школи з малою кількістю учнів».

Саме тому на сьогодні прийнято уживати ще й термін «малочисельна школа. Питання існування малочисельних шкіл України взаємопов'язані з чисельністю населення. Проаналізуємо як співвідносяться дані тенденції з існуванням малочисельних шкіл гірського регіону.

За даними органів статистики, починаючи з 90-х рp. XX ст. сільське населення України зменшується (із 1991 р з 16 млн 969, до 13 млн. 102 тис. у 2017 р. ) (міське 29482) (див. рис.1).

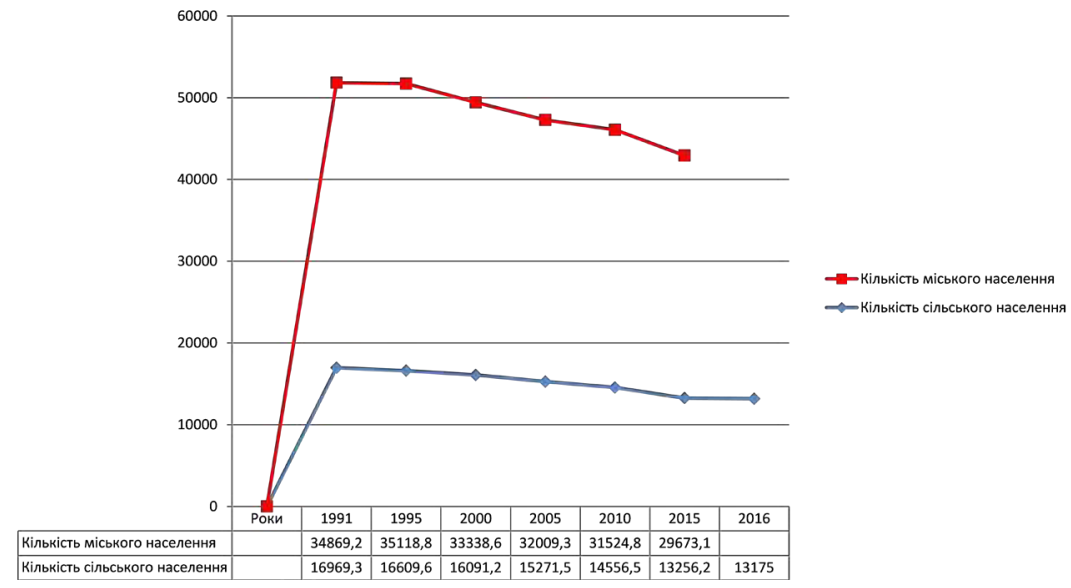

За даними Державної служби статистики України [2]

Рис.1. Чисельність міського та сільського населення в Україні

Слід відзначити, що така тенденція є характерною і для Івано-Франківської області.

Сільське населення Івано-Франківської області зменшилося з 2000р. з 822900) до 2017 р (777900). становить 45 тисяч населення, а це призводить до зменшення наповнюваності значної кількості шкіл. (див. рис. 2).

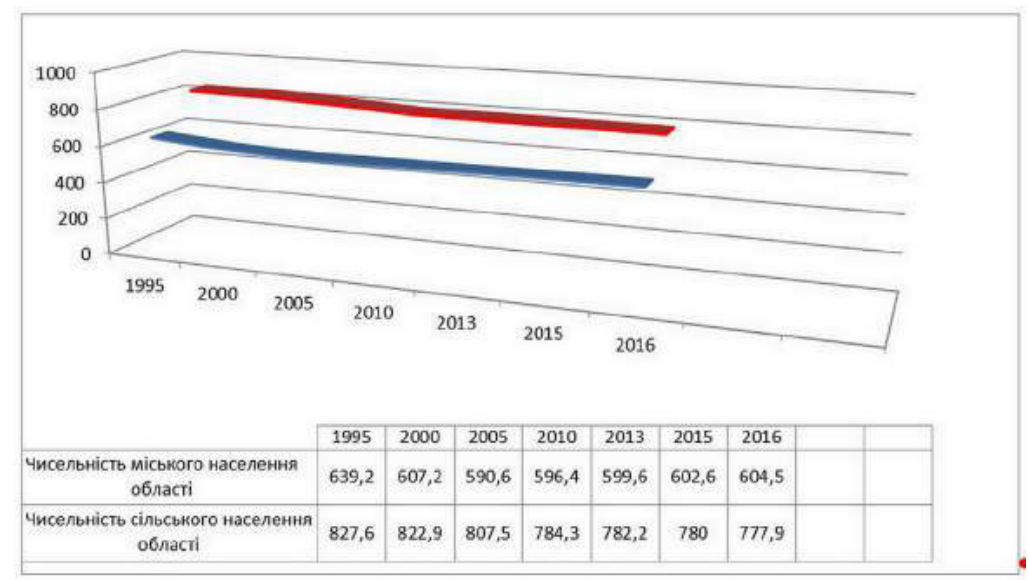

За даними Державної служби статистики України [2]

Рис 2. Чисельність міського та сільського населення Івано-Франківської області 
Як видно з рис. 1 і рис. 2 зменшення кількості населення в Україні та на Івано-Франківщині призводить до зменшення чисельності школярів, а отже і збільшення малочисельних шкіл.

За даними Державної статистики України в українській освіті на початку XXI ст. такі перетворення є стабільними. В сільських регіонах середня наповнюваність початкових шкіл складає 6-11 учнів, неповних середніх - 36- 72, середніх - 100-148 учнів . Ці дані є характерними і для Івано-Франківщини, 2/3 територій якої є гірськими.

Зменшення чисельності школярів, а тим самим розвиток сучасної малочисельної школи гірського регіону, у першу чергу пов'язуємо з демографічними стрибками, виїздом сільського населення за кордон, швидкою урбанізацією. Демографічний спад гірського сільського населення Івано-Франківської області з 2003 р. по 2016 р., становить більше 30 тисяч населення (близько 60\% сільських жителів емігрували за кордон), що призвело до зменшення значної кількості шкіл.

Наведемо ще й інші факти: станом на кінець 2016 р. 3-поміж 718 денних загальноосвітніх навчальних закладів Івано-Франківщини 534 - середні школи I-III ступенів. Більшість шкіл (78,7\%) знаходиться в сільській місцевості, тоді як частка учнів, які навчаються в них, становить 51,6\%.

Безумовно гальмівним чинником розбудови закладів нового типу у сільській місцевості гірських регіонів $є$ і слабкість матеріальної бази, недостатнє кадрове забезпечення малочисельних шкіл, віддаленість більшості сіл від адміністративних центрів. Саме тому тут стає неможливим застосування інноваційних, мультимедійних технологій навчання.

Малочисельність і нерівномірність наповнення класів $€$ найвиразнішими ознаками функціонування і виживання малочисельної школи в умовах гірського регіону. На сьогодні серед важливих аспектів збереження такої школи на Івано-Франківщині є реорганізація чи оптимізація, але ні в якому разі не закриття, що може привести до знищення культури та інтелекту села.

3 іншого боку виникають питання забезпечення якісної освіти та широкого спектру освітніх послуг на селі. Здавалось би вирішенням проблеми $є$ - створення освітніх округів з довезенням учнів автотранспортом. Однак транспорт в умовах гір є складним питанням.

Актуальність проблеми підсилює і факт існування малочисельних шкіл за кордоном. Скажімо малокомплектні і малочисельні школи, в яких навчається 5 і більше учнів існують і в країнах ЄС, США, Фінляндії тощо.

На сучасному етапі розвитку шкільної освіти України малочисельні школи потребують оптимізації, яка має передбачати не занепад та закриття, а модернізацію, трансформацію, надання якісних освітніх послуг.

Згідно з ініціативою українського уряду принцип «середня школа у кожне село» змінюється на мережу опорних шкіл та їхніх філій. Державна політика полягає в тому, що малочисельні школи повинні перетворитися на початкові. Але чи можемо ми закрити всі малочисельні школи? I що з того вийде?

За даними Державної статистики України в українській освіті на початку XXI ст. кількість малочисельних шкіл є чималою (рис.3)

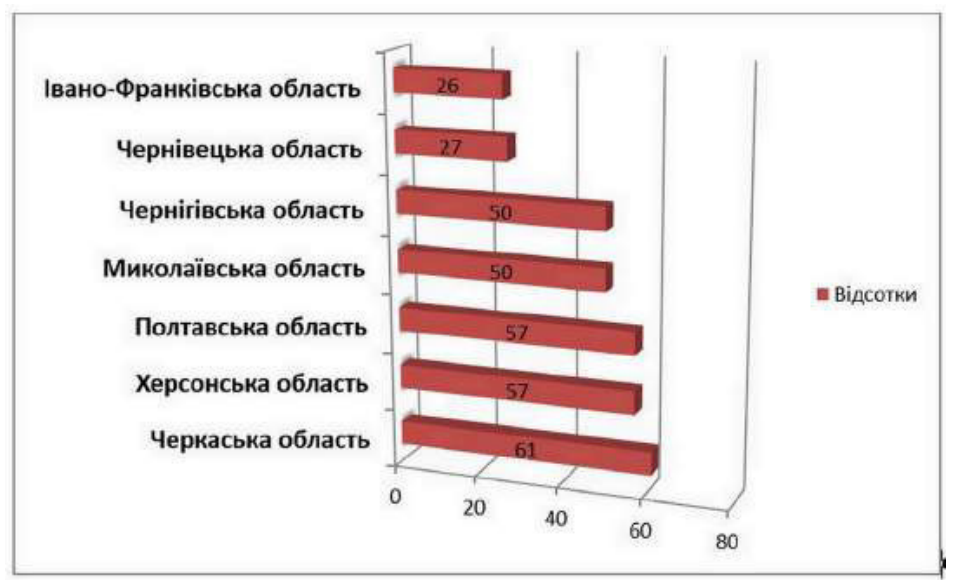

За даними Державної служби статистики України [2]

Рис 3. Відсоток малочисельних шкіл у сільській місцевості України

Найбільше таких шкіл у сільській місцевості України розташовані в Черкаській (61 \%), Херсонській (57 \%), Полтавській (57 \%), Миколаївській (50 \%) та Чернігівській (50 \%) областях. Сл. 10. Кожна четверта загальноосвітня школа I-III ступенів (1 - 11 класи) має менше 100 учнів, тобто може бути закритою.

На сьогодні в Україні ми спостерігаємо дві тенденції -з одного боку, різке зростання чисельності малочисельних шкіл, з іншого - великий відсоток їх закриття. Як видно з діаграм, лише 10\% малочисельних шкіл мають право на життя. 


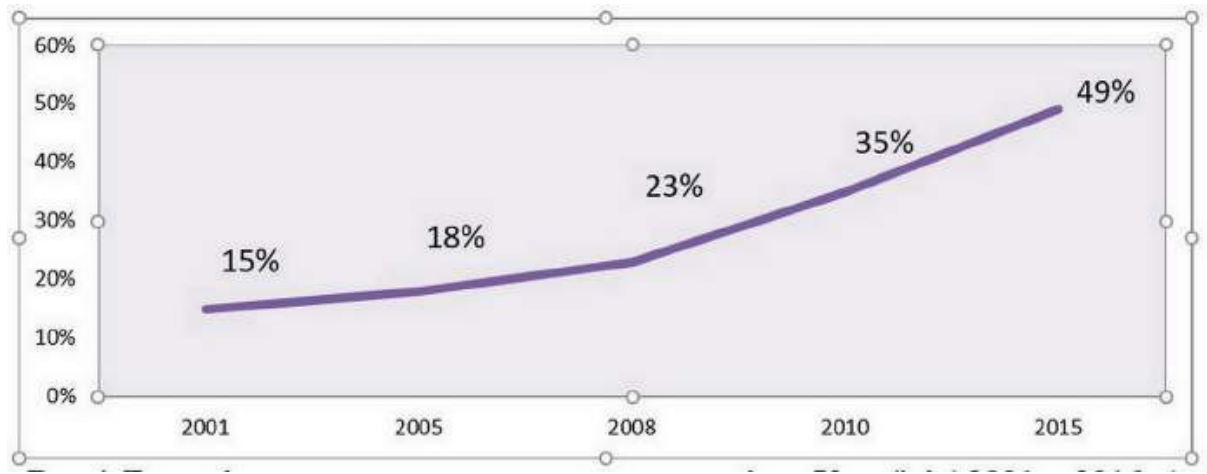

Рис.4 Динаміка зростання малочисельних шкіл в Україні ( 2001 - 2016 р).

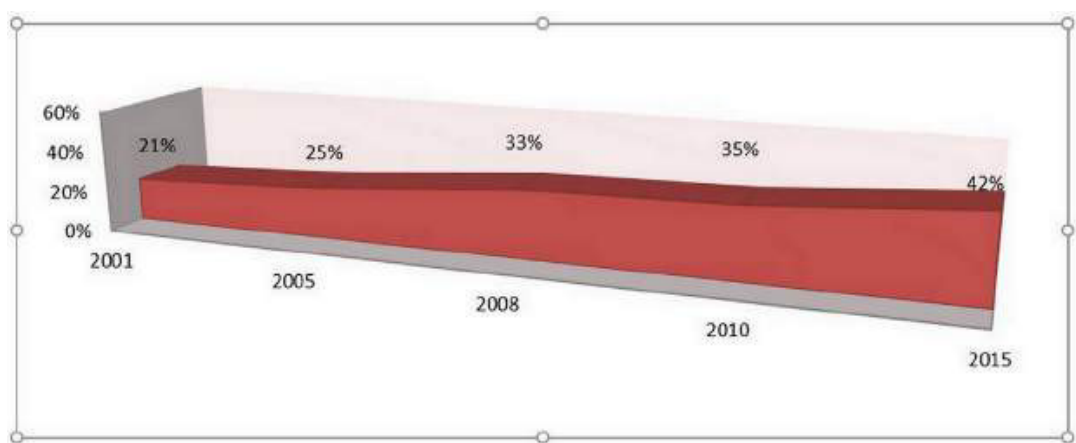

За даними Державної служби статистики України [2]

Рис.5 Динаміка закриття малочисельних шкіл в Україні (2001 - 2016 рр.)

Окрема, як показує статистика станом на початок 2017 н.р. 3701 загальноосвітнього навчального закладу Івано-Франківської області - 560 -- сільських. 3 них 184 - третя частина - малочисельні. Найбільш проблемним $€$ Рогатинський (37 шкіл), Галицький, Косівський та ін. р-ни. Дані статистики засвідчують, що малочисельні школи у гірському регіоні становлять левову частку, є предметом для аналізу і вивчення не лише для науковців, а й для широкої громадськості, державних діячів, політиків (табл.1).

Отже, малочисельність і нерівномірність наповнення класів є найвиразнішими ознаками функціонування малочисельної школи в умовах гірського регіону Івано-Франківщини. У чому ж причина такого стану?

Таблиця 1

Інформація щодо кількості малочисельних навчальних закладів Івано-Франківської області станом на 05.09.2016 року1

\begin{tabular}{|l|c|c|c|c|}
\hline Назва районів, міст & К-сть Н3 & І ст. & I-ІІ ст. & I-ІІІ ст. \\
\hline Богородчанський & 6 & 2 & 4 & \\
\hline Верховинський & 12 & 7 & 5 & \\
\hline Галицький & 24 & 6 & 14 & 4 \\
\hline Городенківський & 10 & 1 & 7 & 2 \\
\hline Долинський & 9 & 5 & 4 & \\
\hline Калуський & 6 & 2 & 4 & \\
\hline Коломийський & 10 & 5 & 3 & 2 \\
\hline Косівський & 11 & 3 & 8 & \\
\hline Надвірнянський & 7 & 6 & & 1 \\
\hline Рогатинський & 37 & 8 & 22 & 7 \\
\hline Рожнятівський & 3 & & 3 & \\
\hline Снятинський & 16 & 8 & 6 & 2 \\
\hline Тисменицький & 11 & 3 & 6 & 2 \\
\hline Тлумацький & 12 & & 12 & \\
\hline м.Болехів & 0 & & & \\
\hline
\end{tabular}




\begin{tabular}{|l|c|c|c|c|}
\hline м. Бурштин & 1 & 1 & & \\
\hline м.Івано-Франківськ & 4 & & & 4 \\
\hline м.Калуш & 0 & & & \\
\hline м.Коломия & 0 & & & \\
\hline м.Яремче & 0 & & & \\
\hline Верхнянська ОТГ & 0 & & & \\
\hline Печеніжинська ОТГ & 2 & & 1 & 1 \\
\hline Старобогородчанська ОТГ & 3 & 2 & 1 & \\
\hline Разом по області & 184 & 59 & 100 & 25 \\
\hline
\end{tabular}

\section{'Департамент освіти, науки та молодіжної політики Івано-Франківської обласної державної адміністрації}

Проблема не в їх існуванні, а в особливостях організації навчальної та виховної роботи, адже сучасна сільська малочисельна школа - це не лише географічне, а й соціальне утворення. У такій школі, на відміну від традиційної класно-урочної системи, доцільними є різноманітні інноваційні технології інтерактивного, індивідуального навчання, диференційованого підходу тощо. Важливим питанням розвитку малочисельних шкіл карпатського регіону. Удосконалення потребує організація роботи сільських малочисельних шкіл через інформатизацію шкільного соціуму, дистанційне навчання.

Існування малої школи має і позитивні сторони, бо створюються сприятливі передумови для індивідуалізації навчальної і виховної роботи, взаємовпливу дітей, розуміння і сприймання один одного. Саме в умовах гірського регіону ми можемо зберегти здорове покоління, а отже і здорову націю.

Неконкурентноздатність, неможливість фахового зростання, небажання працювати в селі у зв'язку з відсутністю відповідних комунікацій приводить до низького рівня професіоналізму, тому важливим питанням розвитку малочисельної школи гірського регіону Івано-Франківщини (як і України загалом) є і підготовка кваліфікованого фахів. Адже вчителям, які викладають два, три і більше предмети, на уроках необхідно використовувати нові специфічні методики навчання відповідно до особливостей кожного предмета.

Розв'язати дану проблему можливо шляхом зацікавлення молоді у роботі в гірській місцевості, надання молодіжного кредитування, відбудови та реорганізації шкільних приміщень тощо.

Якщо у реальних умовах Івано-Франківської області планувати і формувати оптимальну, найбільш доцільну з точки зору задоволення дитячих потреб і економного витрачання ресурсів, мережу навчальних закладів для сільського населення, забезпечити створення оптимального освітнього середовища - кожна дитина матиме доступ до якісної освіти - сільська малочисельна школа існуватиме.

Здавалось би вирішення проблеми у створенні освітніх округів з довезенням учнів автотранспортом. Однак транспорт в умовах гір є складним питанням, особливо взимку.

Низька оснащеність сільських шкіл методичним і демонстраційним матеріалом. На селі лише 30-40\% шкіл мають кабінети з хімії, географії, біології, іноземних мов і літератури. Трохи більше половини сільських шкіл (53\%) - з математики та фізики і лише 2/3 забезпечені кабінетами української мови і літератури.

За кошти держави зробити все це і зберегти маленьку школу - вкрай важко, позитивним у цьому є досвід країн близького зарубіжжя.( Польщі, Естонії Фінляндії, Нідерландах, США)

Наша держава долає ті ж труднощі, із якими зіткнулася європейська система освіти

Проблеми малокомплектних шкіл у сучасній освітній ситуації різних країн відрізняються, не схожі принципи збереження таких шкіл і освітня практика. Одним з важливих факторів, що впливають на збереження цих установ, $\epsilon$, перш за все, соціальні інституції, які активно функціонують на селі, звичайно, за умови, що демографічна ситуація в конкретному населеному пункті не буде погіршуватися.

Досвід збереження малочисельних шкіл в умовах гірських районів передбачає: запровадження нових підходів в управлінні навчальним закладом партнерство, проектну діяльність, створення громадських організацій тощо), реалізацію дій з вирішення актуальних проблем школи та громади (волонтерські програми, надання послуг для дорослих, створення умов для дошкільної підготовки та ін.), надання допомоги і грантів для молодих педагогів, які готові працювати в регіонах, роботу на платформах дистанційної освіти.

Детальне вивчення питання діяльності малочисельної школи дало можливість нам запропонувати своє бачення трансформації навчально-виховного процесу у малочисельних школах:

- традиційне класно-урочне навчання замінити індивідуальним, розрахованим на кожного конкретного учня, враховуючи психологічні особливості;

• використовувати інноваційні і нетрадиційні технології навчання;

- реалізувати компетентнісний, диференційований, особистісно-орієнтований, індивідуальний підхід, інноваційні технології навчання (алгоритмізацію самостійної роботи учнів, технологію ситуативного моделювання, технологію розвитку критичного мислення, метод проектів, технологію колективного 
групового навчання, ситуації успіху, розробленість науково-методичної, організаційної і фінансової бази, яка забезпечувала б процеси модернізації);

- структурувати предметні курси на укрупнені дидактичні одиниці;

· центр ваги в оцінці знань перенести на кінцеві результати;

- планувати суб'єкт- суб'єктні способи отримання зворотного зв'язку;

• пропагувати цінності українця, патріотизм, збереження високих моральних ідей.

Маємо надію, що у зв'язку з модернізацією малочисельної школи, сітковою взаємодією можливим на сьогодні $€$ механізм розвитку школи на селі та забезпечення державних гарантій доступності, рівних можливостей отримання повноцінної освіти у незалежності, де розташований даний заклад - у селі чи місті.

На основі логістичного вивчення стану управлінських, соціокультурних, психолого-педагогічних, соціальних умов функціонування малочисельних шкіл гірського регіону, ми виокремили важливі аспекти збереження і розвитку малочисельних шкіл, серед них: розробка концепції навчально-виховного процесу в малочисельних школах в умовах інноваційної освітньої політики держави; вивчення особливостей змісту, форм і методів підготовки вчителів, вихователів, практичних психологів, соціальних педагогів в університеті для роботи в малочисельних школах гірського регіону; наукове обґрунтування цільового, мотиваційного, технологічного, контрольного компонентів навчання і виховання в школах такого типу; розкриття специфіки наступності дошкільної, початкової та середньої ланок освіти в умовах карпатського регіону; дослідження стану соціальнопедагогічної підтримки сім'ї та запропонувати шляхи взаємодії комплексу «школа-сім'я-громадськість»; аналіз особливостей адаптації вчителя у невеликому колективі; впровадження в навчально-виховний процес малочисельних шкіл карпатського регіону дистанційних та мультимедійних технологій навчання; розробка рекомендацій щодо оптимізації роботи малочисельних шкіл карпатського регіону та на основі них запропонувати стратегічні напрями розвитку малочисельної школи регіону; вивчення особливостей фахової підготовки вчителів, вихователів, практичних психологів, в університеті для роботи в малочисельних школах карпатського регіону та розробка навчально-методичних комплексів до іх підготовки; надання соціальної, психолого-педагогічної і науково-методичної допомоги вчителям; проведення компаративістського аналізу наукових концепцій, підходів, розробок та практичного досвіду з питань існування, функціонування малочисельної школи карпатського регіону України з країнами $€ C$; об'єднання зусиль науковців університету з ученими $€ С$ з метою дослідження проблем розвитку малочисельної школи карпатського регіону. ДВНЗ «Прикарпатський національний університет імені Василя Стефаника» міг би стати таким об'єднуючим науковим центром.

Висновки і перспективи подальших досліджень. Все вище викладене підводить до висновків, що малочисельні школи в гірських регіонах України мають право на існування за умов співпраці органів влади, громадськості, науковців, меценатів, керівників навчальних закладів, педагогічної громадськості, батьків, які через посередництво та залучення фінансів зможуть відкрити грантові програми, допомогти зберегти малу школу і село.

Пропонована стаття не вичерпує всіх аспектів проблеми. Перспективними напрямками нашого дослідження $€$ створення на основі громадського фінансування навчально-виховних закладів «Сільська школа як місцевий освітньо-консультаційний центр розвитку та збереження економіки та культури».

1. Департамент освіти, науки та молодіжної політики Івано-Франківської обласної державної адміністрації. - [Електронний ресурс]. - [Режим доступу] osvitadep.if.ua

2. Державна служба статистики України. - [Електронний ресурс]. - [Режим доступу] //http:www.ukrstat.gov.ua

3. Закон України «ПРО загальну середню освіту» (Відомості Верховної Ради України (ВВР), 1999, № 28 - [Електронний ресурс] . - [Режим доступу] // zakon.rada.gov.ua/laws/show/651-1

4. Круглий стіл «Малочисельна школа Карпатського регіону - [Електронний ресурс]. - [Режим доступу]// http://www.pu.if. ua/.../5758-kruhlyi-stil-malochyselna-shkola-karpatskoho-rehionu-innovat

5. Прокопів Л. Цільовий компонент організації виховної роботи у малокомплектній школі України (друга половина XX ст.) / Л. Прокопів // Людинознавчі студії. Педагогіка. - 2016. - Вип. 2(34). - С. 196-203

\section{Reference}

1. Departament osvity, nauky ta molodizhnoyi polityky Ivano-Frankivs`koyi oblasnoyi derzhavnoyi administraciyi. - [Elektronnyj resurs] . - [Rezhym dostupu] osvitadep.if.ua[in Ukrainian]

2. Derzhavna sluzhba statystyky Ukrayiny. - [Elektronny`j resurs]. - [Rezhym dostupu] http://www.ukrstat.gov.ua [in Ukrainian]

3. Zakon Ukrayiny «PRO zagal'nu serednyu osvitu» (Vidomosti Verxovnoyi Rady Ukrayiny` (VVR), 1999, \# 28. - [Elektronny`j resurs]. - [Rezhy`m dostupu] zakon.rada.gov.ua/laws/show/651-1[in Ukrainian]

4. Kruglyj stil «Malochy`sel’na shkola Karpats`kogo regionu [Elektronnyj resurs]. - [Rezhym dostupu] http://www.pu.if.ua/.../5758kruhlyi-stil-malochyselna-shkola-karpatskoho-rehionu-innovat[in Ukrainian]

5. Prokopiv L. Cil’ovyj komponent organizaciyi vyxovnoyi roboty u malokomplektnij shkoli Ukrayiny` (druga polovy’na XX st.) / L. Prokopiv // Lyudy’noznavchi studiyi. Pedagogika. - 2016. - Vy`p. 2(34). - S. 196-203. - Rezhym dostupu: http://nbuv.gov.ua/ UJRN/Lstud_2016_2(34)_22[in Ukrainian] 